Vol. 1 No. 1 Desember 2021, p-ISSN : 2809-4042 | e-ISSN : 2809-4034

\title{
PENGEMBANGAN MEDIA PEMBELAJARAN BERBASIS ANDROID MENGGUNAKAN APPYPIE PADA MATERI PERSAMAAN TRIGONOMETRI
}

\section{FITRI HIDAYATI}

SMA Muhammadiyah 1 Taman

e-mail: fitrihida75@gmail.com

\begin{abstract}
ABSTRAK
Adanya fenomena Covid-19 semakin meningkatkan kesadaran para pendidik untuk dapat memanfaatkan media pembelajaran berbasis teknologi informasi komunikasi agar pembelajaran tetap berjalan dengan baik. Salah satu alternatif media pembelajaran yang mudah dibuat ialah media pembelajaran berbasis android dengan mengunakan appypie. Dengan menggunakan appypie, guru dengan sangat mudah membuat aplikasi/media pembelajaran sendiri yang berisi konten-konten sesuai dengan tujuan pembelajaran yang ingin dicapai tanpa harus memiliki pengetahuan coding atau pemograman. Penelitian ini bertujuan untuk menghasilkan media pembelajaran berbasis android dengan menggunakan appypie yang valid dan efektif bagi peserta didik. Jenis penelitian ini adalah Penelitian dan Pengembangan (R\&D) menggunakan model ADDIE yang terdiri dari lima tahap, 1) Analisis; 2) Perancangan; 3) Pengembangan; 4) Implementasi dan 5) Evaluasi. Instrumen penelitian berupa kuesioner yang digunakan untuk memperoleh data tingkat kelayakan (validitas). Hasil validasi oleh ahli media diperoleh rata-rata sebesar $80,40 \%$ yang termasuk dalam kategori "Layak" digunakan sebagai media pembelajaran. Sedangkan oleh ahli materi diperoleh rata-rata sebesar $86,40 \%$ dengan kategori "Sangat Layak", dan dari respon peserta didik diperoleh rata-rata 95,56\% juga termasuk kedalam kategori "Sangat Layak" digunakan. Berdasarkan hasil penelitian tersebut maka media pembelajaran ini dinyatakan efektif dan layak untuk diimplementasikan dalam proses pembelajaran.
\end{abstract}

Kata Kunci : media pembelajaran, android, appypie.

\section{ABSTRACT}

The Covid-19 phenomenon has increased the awareness of educators to be able to take advantage of learning media that uses communication information technology so that learning continues well. One of learning media that is easy to make is android-based learning media using appypie. By using appypie, teachers easily create their own learning applications/media that contain content according to the learning objectives to be achieved without having to have knowledge of coding or programming. The purpose of this research is to produce android-based learning media using appypie which can be used as an alternative valid and effective learning media for students. This type of study is research and development (R\&D) using the ADDIE model. The ADDIE model consists of five stages, 1) Analysis; 2) Design; 3) Development; 4) Implementation and 5) Evaluation. The Research instruments is questionnaire, which are used to obtain data on the level of worthiness (validity). The results of the validation by media experts obtained an average of $80.40 \%$ which is included in the " feasible" category to be used as learning media. Meanwhile, material experts obtained an average of $86.40 \%$ in the "Very feasible" category, and from the student responses, an average of $95.56 \%$ was obtained which was also included in the "Very feasible" category to use. Based on the results of the study, the learning media was declared effective and feasible to be implemented in the learning process.

Keywords: learning media, android, appypie

\section{PENDAHULUAN}

Pandemi covid-19 telah memberikan dampak pada seluruh aspek kehidupan, tak terkecuali pada bidang pendidikan. Mengubah sistem pembelajaran yang pada awalnya pembelajaran tatap muka menjadi pembelajaran daring (pembelajaran online). Pada saat ini pun sistem pembelajaran di SMA Muhammadiyah 1 Taman masih menerapkan sitem pembelajaran 
tatap muka terbatas, artinya belum sepenuhnya siswa melakukan pembelajaran secara luring. Adanya fenomena pembelajaran daring semakin meningkatkan kesadaran masyarakat akan pentingnya pemanfaatan atau penggunaan teknologi informasi dan komunikasi. Khusunya bagi para pendidik yang dituntut untuk memanfaatkan teknologi informasi dan komunikasi agar pembelajaran tetap berjalan dengan baik.

Pemanfaatan teknologi dapat diterapkan para pendidik dalam penggunaan media pembelajaran. Media pembelajaran merupakan suatu alat bantu dalam menyampaikan informasi kepada peserta didik dan merupakan salah satu faktor penunjang tercapainya tujuan pembelajaran. Sudjana \& Rivai (2017) berpendapat bahwa media pembelajaran bermanfaat untuk membuat pembelajaran lebih menarik sehingga dapat menumbuhkan motivasi dan semangat peserta didik. (Sanaky, 2013) mengatakan bahwa media pembelajaran adalah alat, metode, dan teknik yang digunakan untuk lebih mengefektifkan komunikasi antara pengajar dan pembelajar dalam proses pembelajaran. Penggunaan media yang tepat dalam proses pembelajaran dapat meningkatkan motivasi belajar dan dapat mengurangi sikap pasif siswa. Dengan adanya media pembelajaran guru dan peserta didik dapat saling berinteraksi, membuat suasana pembelajaran lebih menarik atau tidak monoton, efisien, tanpa dibatasi oleh ruang dan waktu, diberbagai tempat, kapanpun dan dimanapun peserta didik dapat belajar (Arsyad, 2015). Oleh karena itu, pemilihan media pembelajaran yang tepat sangat diperlukan terlebih bagi peserta didik yang melakukan pembelajaran secara daring. Dengan pemilihan media yang tepat, tidak ada lagi perbedaaan kualitas pembelajaran antara peserta didik yang melakukan pembelajaran daring maupun luring. Namun berdasarkan survei, proses pembelajaran di SMA Muhammadiyah 1 Taman didominasi penggunaan aplikasi zoom sebagai media pembelajaran. Khusunya pada pembelajaran matematika. Tentunya hal ini membuat peserta didik bosan karena cenderung bersifat teacher centered dan penjelasan materi menggunakan metode ceramah. Hasilnya, peserta didik hanya menguasai secara teoritis saja, sehingga kurang terampil dalam memecahkan masalah. Selain itu, tidak semua peserta didik memiliki waktu atau kesempatan yang sama untuk bergabung di kelas zoom tersebut sehingga peserta didik dapat ketinggalan materi.

Adanya permasalahan tersebut, peneliti memberikan satu alternatif media pembelajaran yang tepat guna, efektif dan dapat menarik minat peserta didik dalam belajar yaitu media pembelajaran berbasis android. Android merupakan sistem operasi berbasis Linux yang diperuntukkan untuk mobile device. Android merupakan sistem operasi yang paling diminati di masyarakat karena memiliki kelebihan seperti sifat open source yang memberikan kebebasan para pengembang untuk menciptakan aplikasi (Savitri, Karim, \& Hasbullah, 2020). Hampir seluruh guru maupun gpeserta didik SMA Muhammadiyah 1 Taman telah menggunakan smartphone berbasis android. Seiring perkembangan teknologi penggunaan smartphone masih berbanding terbalik dengan pemanfaatan smartphone yang belum optimal khusunya di bidang pendidikan. Hal ini terlihat dari masih rendahnya rating-rating media pembelajaran yang ada. Dikalangan peserta didik, smartphone sebagian besar hanya digunakan untuk mengakses games, media sosial seperti instragram, twitter, facebook, dll namun belum mengambil peranan yang signifikan dalam penjunjang pembelajaran. Sedangkan bagi pendidik, smartphone berbasis android digunakan hanya sebatas untuk mencari referensi atau bahan ajar, bukan menggunakan aplikasi khusus yang disiapkan oleh guru sendiri yang berisi konten sesuai dengan tujuan pembelajaran yang ingin dicapai.

Pembuatan media pembelajaran berbasis android yang mudah dibuat dan diaplikasikan yaitu dengan appypie. Alasan memilih appypie sebagai aplikasi media pembelajaran karena pebuatan aplikasi di appypie cukup mudah, tanpa harus memiliki pegetahuan tentang pemograman sebagaimana slogan appypie yaitu "Make an App, as easy as pie," yang mencerminkan kemudahan dalam penggunaan aplikasi ini. Selain itu appypie memiliki fiturfitur yang lengkap, dapat mengintegrasikan aplikasi yang akan dibuat dengan sosial media, website, blog, youtube hingga berbagai multimedia lainnya yang diinginkan. Appypie (Chusni et al., 2018) merupakan suatu website yang menyediakan template dalam pembuatan aplikasi 
android secara gratis dan berbayar. Appypie ini dapat mendukung proses pembuatan aplikasi pembelajaran berbasis Android, Mac OS, Windows Phone, Blackberry, dan HTML 5. Kelebihan appypie dibanding aplikasi yang lain yaitu tidak memerlukan coding (bahasa pemrograman) dalam membuat aplikasi, menyediakan template dalam pembuatan aplikasi android secara gratis dan ukuran file tidak terlalu besar sehingga mudah dioperasikan di smartphone.

Dari hasil penelitian yang dilakukan oleh (Saraswati \& Novallyan, 2017) dalam pengembangan media pembelajaran berbasis android pada materi trigonometri untuk peserta didik SMA kelas $\mathrm{X}$, aplikasi android yang dirancang hanya menampilkan konsep trigonometri dasar yang disajikan dalam bentujk animasi. Terdapat dua keterbatasan dalam kajian penelitian yang dilakukan oleh (Saraswati \& Novallyan, 2017). Pertama, tidak adanya penjelasan materi, contoh soal, kuis interaktif dan tidak adanya pengintegrasian ke link atau web tertentu yang mendukung pemahaman materi. Kedua, aplikasi android yang digunakan yaitu software Android Studio dan juga JDK (Java SE Development Kit) dimana kedua software ini mengharuskan pembuat aplikasi harus menguasai bahasa pemrograman khusunya bahasa java dan XML. Tentuya hal ini, tidak semua guru bisa membuat aplikasi tersebut karea harus mempunyai pengetahuan atau keahlian dalam bahasa pemrograman terlebih dahulu. Selain itu, aplikasi ini menjai lebihh berat jika di instal di smartphone. Oleh karena itu, penelitian ini dimaksudkan membuat pengembangan media pembelajaran berbasis android dengan menggunakan appypie yang dirasa lebih mudah dibuat dan ringan untuk dinstal di smartphone.

Adapun tujuan penelitian ini adalah menghasilkan produk media pembelajaran berbasis android dengan menggunakan appypie yang dapat dijadikan sebagai salah satu alternatif media pembelajaran yang valid dan efektif bagi peserta didik khusunya pada materi persamaan trigonometri. Dengan adanya berbagai kemudahan dan kelebihan yang disediakan oleh appypie diharapkan dapat memudahkan guru dalam membuat suatu aplikasi media pembelajaran sesuai dengan tujuan pembelajaran yang ingin dicapai sehingga guru bukan lagi satu-satunya sumber belajar bagi peserta didik. Selain itu juga diharapkan dapat menumbuhkan semangat dan meningkatkan hasil belajar khususnya pada meteri persamaan trigonometri. Berdasarkan uraian tersebut, penulis ingin melakukan penelitian dengan judul "Pengembangan Media Pembelajaran Berbasis Android Menggunakan Appypie pada Materi Persamaan Trigonometri.

\section{METODE PENELITIAN}

Metode yang digunakan dalam penelitian ini adalah penelitian pengembangan atau research and development $(R \& D)$ dan menggunakan model pengembangan ADDIE yang terdiri atas lima tahapan antara lain: tahap analisis (analysis), desain (design), pengembangan (development), implementasi (implementation), dan evaluasi (evaluation). Menurut (Sugiyono, 2014) metode penelitian pengembangan adalah metode penelitian yang digunakan untuk menghasilkan dan menguji keefektifan produk tertentu. Sampel dalam penelitian ini ialah peserta didik kelas XI IPA 3 SMA Muhammadiyah 1 Taman. Sampel tersebut dijadikan peneliti untuk subjek uji coba media yang dikembangkan serta mengisi kuesioner untuk menanyakan respon atas ujicoba media. Instrumen penelitian berupa kuesioner yakni kuesioner untuk ahli media, ahli materi dan angket untuk peserta didik.

Prosedur penelitian menggunakan lima tahapan antara lain: (1) Tahap analis yaitu analisis lapangan melalui pengamatan secara langsung dan melalui jurnal mengajar berupa google form untuk mengetahui media pembelajaran apa saja yang digunakan saat pembelajaran matematika sehingga ditemukan media apa yang dibutuhkan atau dikembangkan. (2) Tahap desain, meliputi: penetapan KI/KD dan materi, perancangan media (produk), membuat layout atau tampilan menu utama, pengumpulan bahan/materi untuk pembuatan media meliputi, materi berupa tekt maupun video pembelajaran. (3) Tahap pengembangan, meliputi pembuatan media pembelajaran menggunakan appypie pada materi persamaan trigonometri sesuai dengan rancangan yang telah dibuat dan pengujian media oleh ahli media dan ahli materi hingga menghasilkan media pembelajaran yang valid. 
Data hasil validasi ini berupa data kualitatif kemudian dirubah menjadi data kuantitatif. Adapun penilaian validasi tim ahli menggunakan skala likert sebagai berikut.

Tabel 1. Skor Validasi

\begin{tabular}{cc}
\hline Keterangan & Skor \\
\hline Sangat Baik (SB) & 5 \\
\hline Baik (B) & 4 \\
\hline Cukup (C) & 3 \\
\hline Kurang (K) & 2 \\
\hline Sangat Kurang (SK) & 1 \\
\hline
\end{tabular}

Menghitung nilai rata-rata keseluruhan dan tiap komponen penilaian dengan rumus:

$$
\bar{X}=\frac{\sum x}{n}
$$

Keterangan:

$\bar{X} \quad$ : Rata-rata skor tiap komponen penialian

$\sum x \quad$ : Jumlah skor tiap komponen penilaian

$n \quad$ : Jumlah validator

Langkah selanjutnya ialah mengkonversi hasil rata-rata skor tiap komponen yang berupa data kuantitatif menjadi kualitatif. Rata-rata skor tiap komponen tersebut dibandingkan dengan kritria penilaian ideal dengan konversi skor skala 5 (Widoyoko, 2012) dapat dilihat pada Tabel 2 berikut.

Tabel 2. Konversi data kuantitatif menjadi data kulitatif dengan skala 5

\begin{tabular}{c|c|c}
\hline Kategori & Skor & Persentase \\
\hline Sangat layak & $\mathrm{X}>4,2$ & $\mathrm{X}>84 \%$ \\
\hline Layak & $3,4<\mathrm{X} \leq 4,2$ & $68 \%<\mathrm{X} \leq 84 \%$ \\
\hline Cukup Layak & $2,6<\mathrm{X} \leq 3,4$ & $52 \%<\mathrm{X} \leq 68 \%$ \\
\hline Kurang Layak & $1,8<\mathrm{X} \leq 2,6$ & $36 \%<\mathrm{X} \leq 52 \%$ \\
\hline Sangat Kurang Layak & $\mathrm{X} \leq 1,8$ & $\mathrm{X} \leq 36 \%$ \\
\hline
\end{tabular}

(4) Pada tahap implementasi yaitu uji coba produk kepada peserta didik pada saat pembelajaran persamaan trigonometri. Proses uji coba dilakukan dengan menjelaskan cara penggunaan media pembelajaran kepada peserta didik. Setelah peserta didik mencoba, peserta didik diberikan angket respon pengguna media pembelajaran untuk dapat memberi tanggapan tentang media pembelajaran yang dibuat. (5) Tahap evaluasi yaitu tahap akhir dalam proses pengembangan media pembelajaran. Evaluasi dilakukan dengan menganalisis data yang telah diperoleh dan melakukan revisi tahap akhir terhadap media pembelajaran.

\section{HASIL DAN PEMBAHASAN}

\section{Hasil}

Hasil penelitian pengembangan media menggunakan model ADDIE, sesuai tahapan berikut:

\section{Analisis (Analysis)}

Pada tahap ini peneliti melakukan observasi atau pengamatan langsung kepada guru matematika SMA Muhammadiah 1 Taman pada saat proses pembelajaran. Diperoleh hasil bahwa $85 \%$ guru matematika di SMA Muhammadiyah 1 Taman menggunakan zoom pada saat pembelajaran. Hal ini dikarenakan di SMA Muhammadiyah 1 Taman telah menyediakan zoom kelas untuk menunjang pembelajaran secara daring. Berdasarkan jurnal mengajar, selain menggunakan zoom guru memberikan materi dari LKS dan youtube untuk dipelajari dan menggunakan whatsapp grup untuk memberikan tugas kepada peserta didik. Hampir pada semua mata pelajaran guru SMA Muhammadiyah 1 Taman memanfaatkan fasilitas zoom kelas dalam menyampaikan materi pembelajaran. Berdasarkan hasil observasi dan wawancara dengan peserta didik SMA Muhammadiyah 1 Taman, didapatkan bahwa peserta didik merasa bosan ketika hampir disemua mata pelajaran menggunakan zoom karena lebih menggunakan metode ceramah. Terdapat beberapa kekurangan ketika menggunakann zoom antara lain : terkadang terkendala jarigan internet sekolah sehingga penyampaian materi tidak maksimal, perlu banyak kuota yang diperlukan, tidak semua guru melakukan rekaman pembelajaran 
(screen record) sehingga peserta didik yang berhalangan tidak dapat mempelajari ulang. Media pembelajaran matematika yang diinginkan peserta didik yaitu media pembelajaran yang fleksibel artinya peserta didik bisa mempelajari materi kapan pun dan dimana pun dengan mudah. Media yang lengkap, tidak hanya berisi materi dan soal namun juga terintegrasi dengan video pembelajaran dari guru dan dapat berinteraksi dengan guru. Berdasarkan kebutuhan tersebut, maka dibuatlah sebuah media yang dapat memenuhi kebutuhan guru maupun peserta didik. Media tersebut kemudian diimplementasikan dalam pembelajaran metematika.

\section{Perancangan (Design)}

Tahap desain merupakan tahap perancangan produk yang sesuai dengan hasil analisis yang telah dilakukan sebelumnya. Adapun langkah-langkah tahap perancangan ini antara lain : a) Pemilihan materi serta Kompetensi dasar. Dalam penelitian ini, materi yang digunakan adalah persamaan trigonometri kelas XI semester ganjil. b) Mengumpulkan bahan untuk kebutuhan pembuatan media seperti meteri, video pembelajaran, soal-soal persamaan trigonometri, dan pendukung media lainnya seperti icon, foto, wallpaper dll. c) Membuat desain flowchart halaman utama sebagai acuan bagi peneliti dalam merancang desain media pembelajaran agar terkonsep dengan baik.

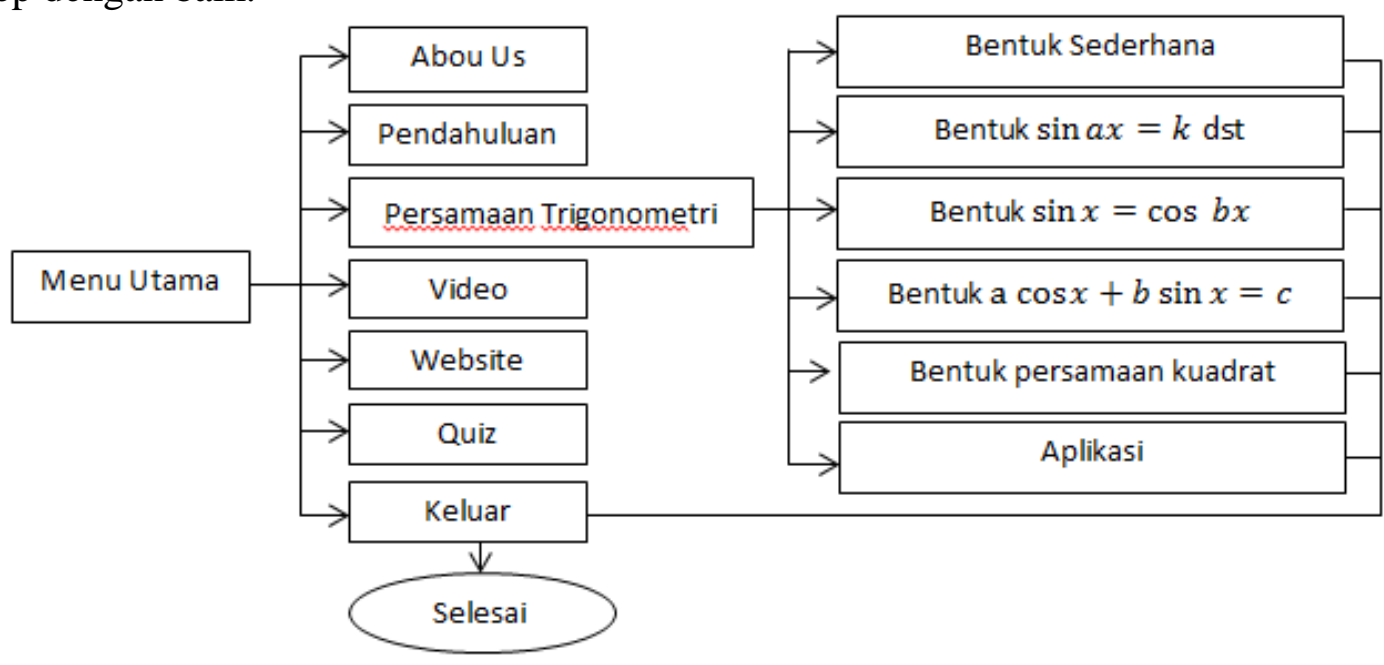

Gambar 1. Flowchart media pembelajaran

\section{Pengembangan (Development)}

Pada tahap ini peneliti melakukan pembuatan dan pengujian produk. Langkah awal dalam membuat media pembelajaran berbasis android dengan menggunakan appypie ialah mendaftar "signup" melalui website appypie yaitu www.appypie.com kemudian mulai membuat menumenu sesuai dengan rancangan pada flowcart yang telah dibuat. Produk yang dihasilkan oleh appypie berupa aplikasi (.apk) yang nantinya bisa diakses pada sistem android melalui link atau juga dapat didownload di playstore. 


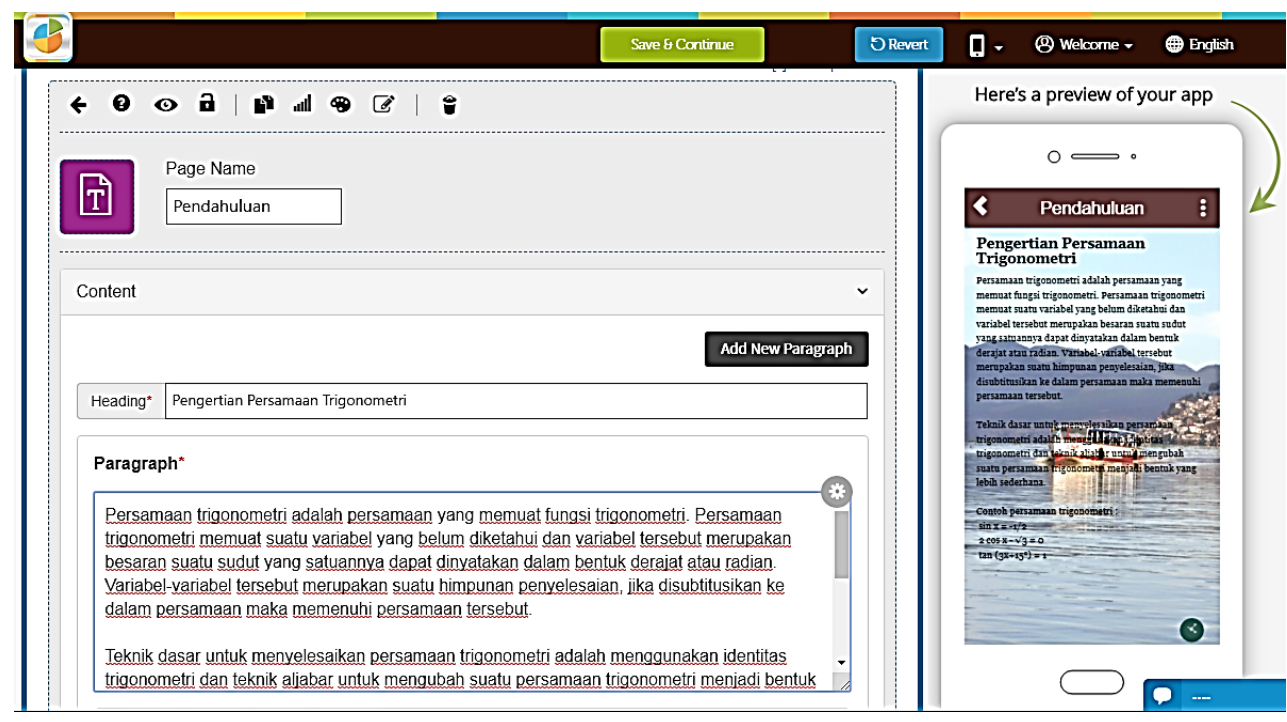

Gambar 2: Proses input materi pembelajaran di appypie

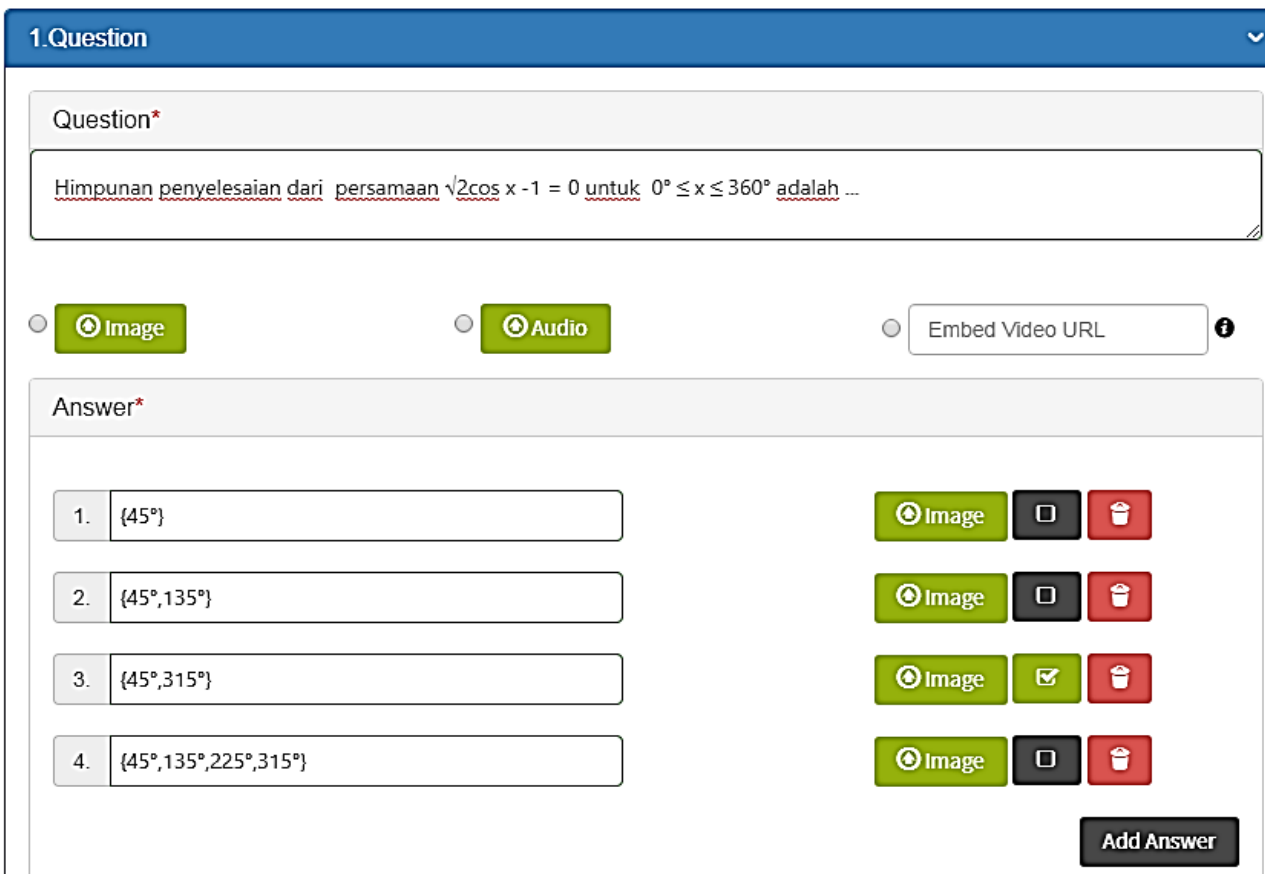

Gambar 3 : Proses pembuatan kuis 

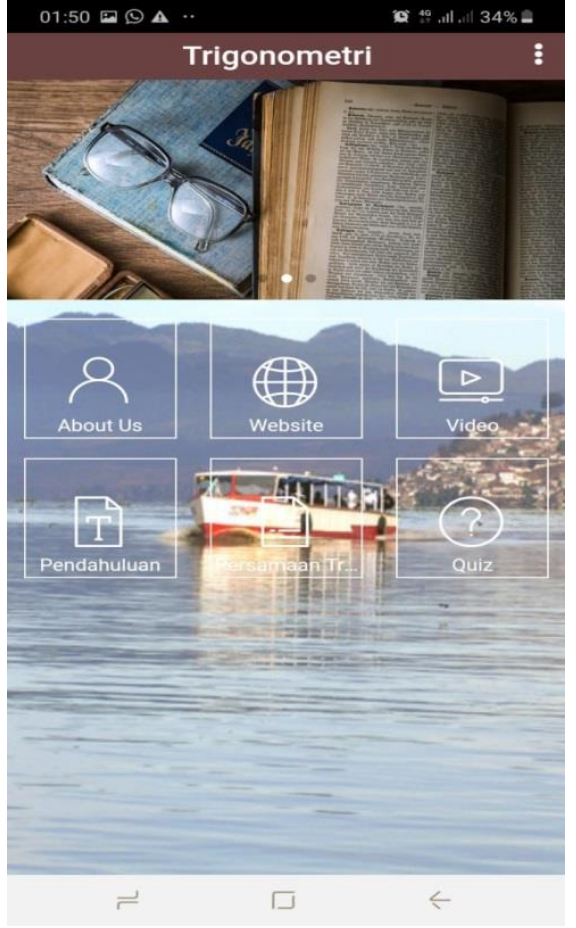

Gambar 4 : Tampilan halaman utama di smartphone siswa
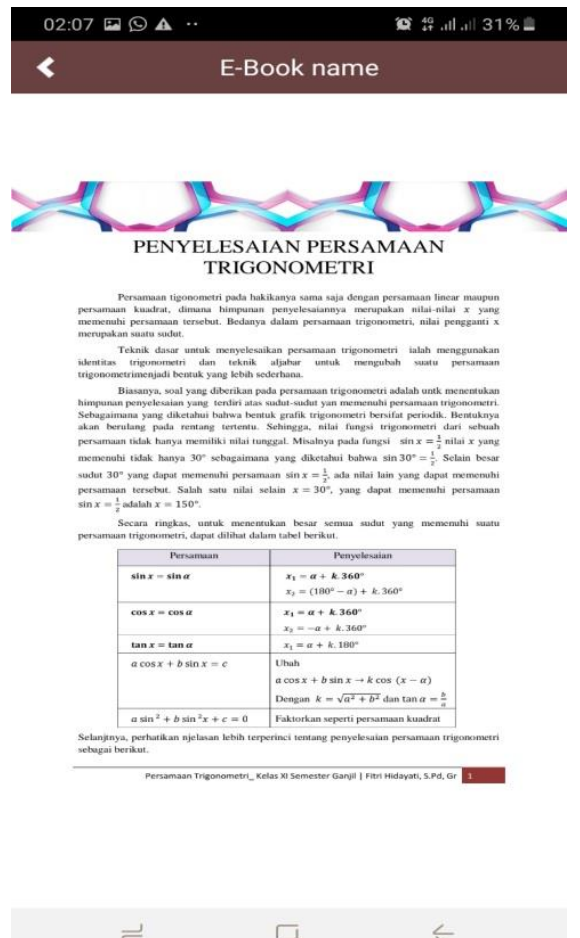

\section{Gambar 6 : Tampilan Menu Materi}

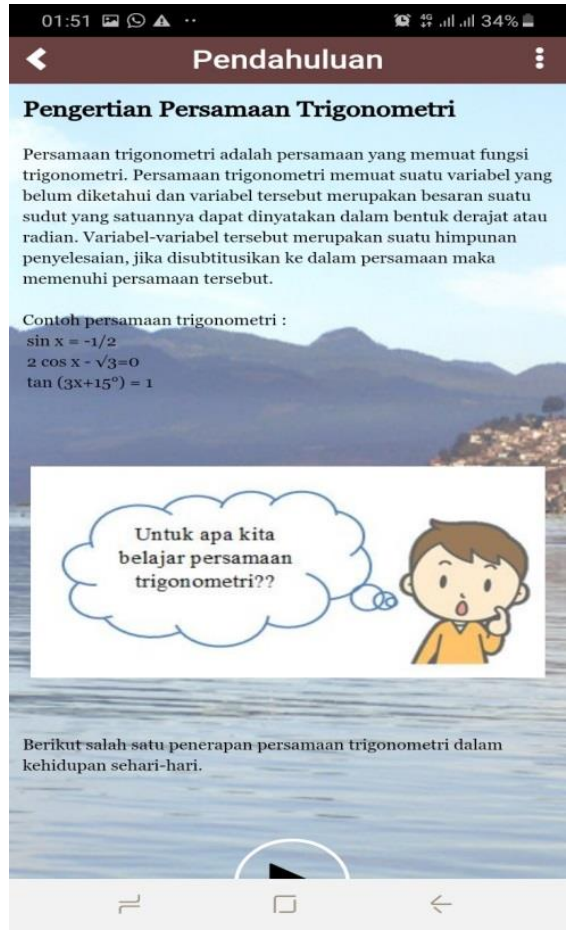

Gambar 5 : Tampilan menu pendahuluan

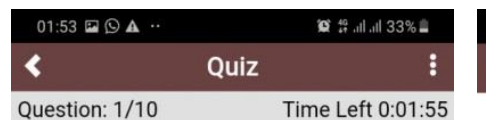

Question: 1/10 Time Left 0:01:55

Nilai $x$ yang memenuhi persamaan trigonometri $\cos 2 x+$ $7 \sin x-4=0$ untuk $0^{\circ} \leq x \leq 360^{\circ}$ adalah

\begin{tabular}{lll}
\hline $30^{\circ}$ dan $135^{\circ}$ & & \\
\hline $30^{\circ}$ dan $150^{\circ}$ & & \\
\hline${ }^{45^{\circ} \text { dan } 150^{\circ}}$ & \\
\hline $0^{60^{\circ} \text { dan } 135^{\circ}}$ & & \\
\hline & & \\
& Submit & \\
\hline
\end{tabular}

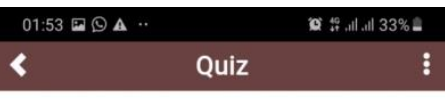

Your Result:

Questions Asked 10

Correct Questions 2

Incorrect Questions 7

Question Skipped 1

Question Not Attempted 0

Time Elapsed 0:00:30

Final Score 20\%

Sorry! You failed in the quiz. Please try again

Passing Score $70 \%$

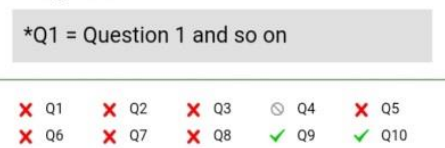

Setelah pembuatan media pembelajaran selesai, langkah selanjutnya ialah menguji atau memvalidasi produk oleh dua ahli media dan dua ahli materi. Hasil validasi diukur dengan menggunakan skala 5 yaitu: sangat kurang baik (1), kurang(2), cukup (3), baik (4), dan sangat baik (5). Hasil validasi oleh tim ahli media disajikan pada Tabel 3 berikut. 
Tabel 3. Hasil validasi ahli media

\begin{tabular}{c|c|c|c|c}
\hline \multirow{2}{*}{ No } & \multirow{2}{*}{ Aspek } & Ahli media I & Ahli media II & \multirow{2}{*}{ Rerata } \\
\cline { 2 - 4 } & Konten/Isi & 4,50 & 4,00 & 4,25 \\
\hline 2 & Efisiensi & 3,67 & 4,00 & 3,83 \\
\hline 3 & $\begin{array}{c}\text { Bahasa/petunjuk } \\
\text { penggunaan }\end{array}$ & 4,50 & 4,50 & 4,50 \\
\hline 4 & Tampilan Visual & 3,67 & 3,33 & 3,50 \\
\hline \multicolumn{3}{c|}{ Rata-rata keseluruhan } & $\mathbf{4 , 0 2}$ \\
\hline \multicolumn{3}{c|}{ Persentase } & $\mathbf{8 0 , 4 \%}$ \\
\hline \multicolumn{3}{c|}{ Kategori } \\
\hline
\end{tabular}

Kedua hasil validasi ahli media pada seluruh aspek penilaian diperoleh rata-rata sebesar 4,02 dengan persentase nilai 80,4\% yang masuk dalam kategori "Layak" digunakan sebagai media pembelajaran. Sedangkan untuk hasil validasi ahli materi disajikan pada Tabel 4 berikut.

Tabel 4. Hasil validasi ahli materi

\begin{tabular}{c|c|c|c|c}
\hline \multirow{2}{*}{ No } & \multirow{2}{*}{ Aspek } & \multicolumn{2}{|c|}{ Hasil Penilaian } & \multirow{2}{*}{ Rerata } \\
\cline { 2 - 4 } & Relevansi materi & 4,00 & 4,50 & 4,25 \\
\hline 1 & 3,50 & 4,00 & 3,75 \\
\hline 2 & $\begin{array}{c}\text { Pengorganisasian \& } \\
\text { Evaluasi }\end{array}$ & 5,00 & 4,50 & 4,75 \\
\hline 3 & Bahasa & 4,67 & 4,33 & 4,50 \\
\hline 4 & Kuis & 4,00 & 4,33 \\
\hline 5 & $\begin{array}{c}\text { Efek bagi strategi } \\
\text { pembelajaran }\end{array}$ & 4,67 & & $\mathbf{4 , 3 2}$ \\
\hline \multicolumn{3}{c}{ Rata-rata keseluruhan } \\
\hline \multicolumn{3}{c}{ Persentase } & $\mathbf{8 6 , 4 \%}$ \\
\hline \multicolumn{3}{c}{ Kategori } \\
\hline
\end{tabular}

Berdasarkan Tabel 4 diperoleh bahwa penilaian media pembelajaran appypie berdasarkan seluruh aspek penilaian ahli materi mendapatkan nilai rata-rata 4,32 dengan persentase nilai $\mathbf{8 6 , 4 \%}$ yang berada pada kategori "Sangat Layak" digunakan sebagai media pembelajaran persamaan trigonometri.

\section{Implementasi (Implementation)}

Implementasi dilakukan dengan menyebarkan media pembelajaran kepada 33 peserta didik kelas XI IPA 3 SMA Muhammadiyah 1 Taman baik peserta didik yang melakukan pembelajaran daring maupun luring. Sebelum media digunakan peserta didik terlebih dahulu diminta untuk menginstall aplikasi appypie yang telah dibuat pada smartphone masing-masing melalui link yang dibagikan melalui whatsapp group kelas XI IPA 3. Setelah siswa selesai menginstall dan menggunakan media tersebut, selanjutnya siswa diminta untuk mengisi kuesioner respon peserta didik yang telah diberikan melalui link google form. Berikut disajikan rekapitulasi jawaban dari peserta didik kelas XI IPA 3 SMA Muhammadiyah 1 Taman.

Tabel 5. Hasil rekapitulasi kuesioner respon peserta didik

\begin{tabular}{|c|l|c|c|c|}
\hline \multirow{2}{*}{ No } & \multicolumn{1}{|c|}{ Pernyataan } & \multicolumn{1}{|c|}{ Jawaban } & \multirow{2}{*}{ Persentase } \\
\cline { 2 - 4 } & $\begin{array}{l}\text { Ya } \\
\text { Aplikasi media pembelajaran berbasis android menggunakan } \\
\text { appypie dapat meningkatkan minat atau motivasi saya dalam } \\
\text { mempelajari persamaan trigonometri. }\end{array}$ & 30 & 3 & $90,90 \%$ \\
\hline 2 & $\begin{array}{l}\text { Saya lebih senang belajar dengan menggunakan media } \\
\text { pembelajaran berbasis android menggunakan appypie dari pada } \\
\text { hanya mendengarkan penjelasan guru. }\end{array}$ & 33 & 0 & $100 \%$ \\
\hline 3 & $\begin{array}{l}\text { Media pembelajaran ini dapat memberikan kesempatan kepada } \\
\text { saya untuk belajar kapanpun dan dimanapun (fleksibel) }\end{array}$ & 33 & 0 & $100 \%$ \\
\hline
\end{tabular}




\begin{tabular}{|c|c|c|c|c|}
\hline \multirow{2}{*}{ No } & \multirow{2}{*}{ Pernyataan } & \multicolumn{2}{|c|}{ Jawaban } & \multirow{2}{*}{ Persentase } \\
\hline & & $\mathrm{Ya}$ & Tidak & \\
\hline 4 & $\begin{array}{l}\text { Menurut saya aplikasi media pembelajaran ini penting } \\
\text { penggunaanya dalam mempelajari peersamaan trigonometri. }\end{array}$ & 31 & 2 & $93,93 \%$ \\
\hline 5 & $\begin{array}{l}\text { Isi materi yang disajikan lengkap sehingga membantu saya dalam } \\
\text { memahami persamaan trigonometri. }\end{array}$ & 30 & 3 & $90,90 \%$ \\
\hline 6 & Bahasa yang digunakan sederhana dan mudah dipahami & 33 & 0 & $100 \%$ \\
\hline 7 & $\begin{array}{l}\text { Media ini membantu kesulitan belajar saya dalam mempelajari } \\
\text { persamaan trigonometri }\end{array}$ & 29 & 4 & $87,87 \%$ \\
\hline 8 & $\begin{array}{l}\text { Adanya media pembelajaran berbasis android dengan } \\
\text { menggunakan appypie, saya mendapatkan pengetahuan yang lebih } \\
\text { mendalam tentang persamaan trigonometri }\end{array}$ & 30 & 3 & $90,90 \%$ \\
\hline 9 & $\begin{array}{l}\text { Saya dapat belajar secara aktif dan mandiri dengan media } \\
\text { pembelajaran berbasis android dengan menggunakan appy pie }\end{array}$ & 33 & 0 & $100 \%$ \\
\hline 10 & $\begin{array}{l}\text { Adanya kuis dalam aplikasi media pembelajaran berbasis android } \\
\text { menggunakan appypie dapat mengasah kemampuan saya dalam } \\
\text { menyelesaikan masalah terkait persamaan trigonometri. }\end{array}$ & 33 & 0 & $100 \%$ \\
\hline 11 & Materi yang disajikan dikemas secara sistematis dan menarik & 29 & 4 & $87,87 \%$ \\
\hline 12 & $\begin{array}{l}\text { Menurut saya desain media pembelajaran berbasis android } \\
\text { menggunakan appypie memiliki tampilan yang menarik dan } \\
\text { lengkap karena adanya fitur-fitur pendukung (gambar, video, kuis, } \\
\text { web dll). }\end{array}$ & 33 & 0 & $100 \%$ \\
\hline 13 & $\begin{array}{l}\text { Aplikasi media pembelajaran berbasis android menggunakan } \\
\text { appypie mudah dalam penggunaannya. }\end{array}$ & 33 & 0 & $100 \%$ \\
\hline & Rata-Rata & & & $95,56 \%$ \\
\hline
\end{tabular}

Berdasarkan tabel 5 diperoleh bahwa hampir seluruh pernyataan mendapatkan respon positif dan mendapat rata-rata sebesar $\mathbf{9 5 , 5 6 \%}$. Persentase tersebut termasuk ke dalam kriteria "Sangat Layak" untuk digunakan dalam pembelajaran.

\section{Evaluasi (Evaluation)}

Tahapan evaluasi pada penelitian dan pengembangan ini, diperoleh dari saran, pendapat dan masukan yang diberikan oleh validator ahli terhadap media pembelajaran berbasis android menggunakan appypie. Hasil saran, pendapat, dan masukan tersebut digunakan oleh peneliti untuk melakukan revisi produk yang dikembangkan.

\section{Pembahasan}

Adanya pandemi covid-19 ini mendorong guru untuk meningkatkan keterampilannya dalam merancang atau mendesain pembelajaran berbasis teknologi. Telah banyak platform yang tersedia dalam menunjang pembelajaran. Hanya saja tidak semua platform tersebut sesuai dengan kebutuhan guru dalam mencapai tujuan pembelajaran yang diinginkan. Appypie merupakan salah satu platform yang menyediakan para "creator" untuk berkreasi menciptakan suatu aplikasi dengan mudah tanpa adanya coding. Tak terkecuali bagi guru, guru dapat menambahkan materi maupun kuis berupa teks, audio, video, malampirkan file bahkan dapat dintegrasikan ke website maupun sosial media. Tentunya fitur-fitur yang telah dibuat dapat membantu proses pembelajaran khususnya pada materi persamaan trigonometri.

Hasil temuan pada penelitian ini diperoleh bahwa media pembelajaran dengan menggunakan appypie merupakan hal yang baru bagi guru maupun peserta didik SMA Muhammadiyah 1 Taman. Media pembelajaran dengan menggunakan appypie sangat layak atau efektif untuk digunakan dalam pembelajaran. Hal ini sejalan dengan penelitian yang dilakukan oleh (Yanti \& Huda, 2020) yang berjudul Analisis Tingkat Kelayakan Aplikasi Android "Appypie" Sebagai Media Pembelajaran menyimpulkan bahwa aplikasi appypie sebagai media pembelajaran Teknik Pemrograman Mikroprosesor dan Mikrokontroler masuk dalam kategori "Sangat Baik" dan dapat dikatakan "Valid" atau layak digunakan. Selain itu, penelitian (Taufan \& Nurafifah, 2021) berdasarkan hasil temuan diperoleh bahwa aplikasi 
mobile learning terintegrasi Appy Pie layak digunakan untuk pembelajaran geometri di kelas VIII SMP.

\section{KESIMPULAN}

Berdasarkan hasil penelitian dan pembahasan yang telah dijelaskan, maka dapat ditarik simpulan sebagai beirkut: Penelitian yang telah dilakukan menghasilkan sebuah produk yaitu media pembelajaran berbasis android dengan menggunakan appypie pada materi permasamaan trigonometri. Hasil validasi oleh ahli media diperoleh rata-rata sebesar $\mathbf{8 0 , 4 0 \%}$ yang termasuk dalam kategori "Layak" digunakan sebagai media pembelajaran. Sedangkan oleh ahli materi diperoleh rata-rata sebesar $\mathbf{8 6 , 4 0 \%}$ dengan kategori "Sangat Layak", dan dari respon peserta didik diperoleh rata-rata 95,56\% juga termasuk kedalam kategori "Sangat Layak" digunakan.

\section{DAFTAR PUSTAKA}

Arsyad, Azhar. (2015). Media Pemblajaran. Jakarta: Raja Grafindo Persada.

Chusni, Muhammad Minan. dkk. (2018). APPY PIE UNTUK EDUKASI Rancang Bangun Media Pembelajaran Berbasis Android. Yogyakarta: Media Akademi.

Sanaky, Dr. Hujair AH. (2013). Media Pembelajaran Interaktif-Inovatif. Yogyakarta: Kaukaba Dipantara.

Saraswati, E \& Novallyan, D. (2017). Pengembangan Media Pembelajaran Interaktif Berbasis Android Untuk Pemahaman Konsep Trigonometri. Indonesian Journal of Educational Research. 2(2), 72-76, from doi: https://doi.org/10.30631/ijer.v2i2.37.

Savitri, D., Karim, A., \& Hasbullah. (2020). Pengembangan Media Pembelajaran Matematika Berbasis Android di Kelas 4 Sekolah Dasar. Lebesgue : Jurnal Ilmiah Pendidikan Matematika, Matematika dan Statistika, 1(2), 63-75, from doi: http://dx.doi.org/10.46306/lb.v1i2.

Sudjana, N., \& Rivai, A. (2017). Media Pengajaran. Bandung: Sinar Baru Algensindo. Sugiyono. (2014). Metode Penelitian Pendidkan (Pendekatan Kuantitatif, Kualitatif dan R\&D). Bandung: Alfabeta.

Taufan, M., Nurafifah, L. (2021). Mobile Learning Terintegrasi Appy Pie: Desain dan Kelayakannya untuk Membantu Proses Pembelajaran Geometri 3D di Masa Pandemi Covid 19. Math Didactic: Jurnal Pendidikan Matematika. 7(2), 124-132, from doi: https://doi.org/10.33654/math.v7i2.1329.

Widoyoko, Eko Putro. (2012). Evaluasi Program Pembelajaran. Yogyakarta: Pustaka Belajar.

Yanti, N. S., \& Huda, Y. (2020). Analisis Tingkat Kelayakan Aplikasi Android "Appypie" sebagai Media Pembelajaran. Jurnal Vocational Teknik Elektronika dan Informatika. 8(4), 114-120, from doi: https://doi.org/10.24036/voteteknika.v8i4.110256. 